\title{
Instability of Nucleic Acids in Airborne Microorganisms under Far Infrared Radiation
}

\author{
En-Jing Li', Jun Lu², Shu-Ming Dong2, Mei-Zi Zhang'3 , Steven Cen4, Lian-Jing Li5, Wei-Hong Huang6* \\ ${ }^{1}$ Office of Environmental Protection and office of Radiation Protection, Peking University, Beijing, China \\ ${ }^{2}$ LEXIHY (Beijing) Technology Co., Ltd., Beijing, China \\ ${ }^{3}$ Reproductive Medicine Center, Tianjin First Central Hospital, Tianjin, China \\ ${ }^{4}$ CEN New Material Co., Ltd., Ningbo, China \\ ${ }^{5}$ Renmin University of China, Beijing, China \\ ${ }^{6}$ State Key Laboratory of Molecular Developmental Biology, Institute of Genetics and Developmental Biology, Chinese Academy \\ of Sciences, Beijing, China \\ Email: ^huang343@genetics.ac.cn
}

How to cite this paper: Li, E.-J., Lu, J., Dong, S.-M., Zhang, M.-Z., Cen, S., Li, L.-J. and Huang, W.-H. (2020) Instability of Nucleic Acids in Airborne Microorganisms under Far Infrared Radiation. Health, 12, 998-1007.

https://doi.org/10.4236/health.2020.128074

Received: July 20, 2020

Accepted: August 14, 2020

Published: August 17, 2020

Copyright $\odot 2020$ by author(s) and Scientific Research Publishing Inc. This work is licensed under the Creative Commons Attribution International License (CC BY 4.0).

http://creativecommons.org/licenses/by/4.0/

\begin{abstract}
Emergence of zoonotic-human pathogens is proven to be a lethal threat to public health, and RNA virus including influenza viruses, severe acute respiratory syndrome coronavirus, middle east respiratory syndrome coronavirus, and COVID-19, plays a pivotal role. As those viruses as airborne microorganisms spread mainly by tiny airborne particles, it is important to de-active those airborne particles before their entry into human bodies. In this study, we investigated the effect of far infrared (FIR) radiation on inhibition of airborne microorganisms. The result confirmed that double stand DNA from airborne microorganisms containing RNA viruses was stable under mild FIR radiation. However, single strand RNA from them was found to be sensitive to FIR radiation, indicating that RNA virus in airborne particles is instable under FIR radiation. Based on this observation, two models on usage of FIR radiation to prevent RNA virus transmission by air and cure RNA virus infection were proposed. Then, this study suggests that FIR radiation has the potential to be a cheap, convenient, and efficient method in clinic to treat RNA virus.
\end{abstract}

\section{Keywords}

RNA Virus, Far Infrared, Radiation, Influenza Virus, COVID-19

\section{Introduction}

RNA virus, such as influenza virus and COVID-19 virus, has been inflicting 
human being for a long period. In history, "Spanish" influenza pandemic occurred worldwide and this influenza virus had killed 50 - 100 million people in 1918-1919 [1] [2]. Today, influenza virus still affects 9 - 35 million people each year, and the annual rate of influenza-associated death in the United States overall ranged from 1.4 to 16.7 deaths per 100,000 persons [3] [4] [5]. Till February 19, 2020, COVID-19 virus has been spreading to over 50 countries with more than 3000 deaths and 150,000 confirmed cases [6] [7]. As traditional immune methods take a long period to prevent and cure RNA virus infection, new convenient ways that can be used immediately in clinic are eagerly needed.

In winter, far infrared (FIR) heating fan is always used to warm homes, which in fact makes FIR fan everywhere in northern China. The FIR fan generates FIR light to heat the air, which is a type of electromagnetic radiation. Generally, FIR wavelength ranges from $5.6-1000 \mu \mathrm{m}$, which is above those of microwaves and longer than those of visible light [8]. Thus, FIR is invisible to the human eye, and in fact the human itself emits FIR [9]. FIR can penetrate up to about 4 centimeters beneath human skin, and can stimulate proliferation of cells and tissues, which makes FIR a promising treatment for cardiovascular malfunction, pain, inflammation, skin itches and some chronic health problems [10] [11] [12] [13]. As modern FIR fans efficiently deliver FIR radiation, which makes them safe and effective for warming, physical health, stress, fatigue and ordinary usage [14]. As FIR radiation is a non-ionizing form of radiation, it does not affect double strand DNA under normal conditions [15] [16] [17]. However, currently if FIR radiation could induce degeneration of single strand RNA in airborne microorganisms is largely elusive. In this study, we measured the stability of RNA in airborne microorganisms under different FIR radiation dosages. The result showed that single strand RNA from them was found to be sensitive to FIR radiation, which implies that FIR radiation is potential to be a convenient way that can be used immediately in clinic to treat RNA virus infection.

\section{Materials and Methods}

\subsection{Materials and Reagents}

The FIR heating fan was purchased from a local supermarket. Its physical properties are listed below: defined voltage: model: DF825 (Pioneer, Inc); $220 \mathrm{~V}$; weight: $1.4 \mathrm{~kg}$; defined wattage: $400 / 800 \mathrm{~W}$. The rooms used for the experiments were two rooms with similar size (width $\times$ length $\times$ height: 2.5 meter $\times 8.5$ meter $\times 2.4$ meter) in the first floor near a fresh food market in Beijing. Before those experiments, the air-tight windows of the two rooms were open to let the environmental air to entry. From December 1, 2013 to June 1, 2014, air particle samples were taken every two weeks. DEPC (diethyl pyrocarbonate) was purchased from Sigma, and Trizol was purchased from Thermo Fisher company. The advices for graphene FIR was supplied by LEXIHY (Beijing) Technology Co. and CEN New Material Co., Ltd. (Founded in 2011, CEN New Material Co., Ltd. is a nationally known high-tech company that focuses on research, production, and 
sales of various polyimide products.).

\subsection{Sample Collection}

Before sampling, the air-tight windows and doors were closed to prevent interference of environmental air particle. In control room, there were not any treatments. In another room, a FIR fan was used to radiate the air for different time. Then, a simplified air-particle collector (Figure 1(c)) was used to accumulate particles in the air. The $1000 \mathrm{ml}$ collection bottle was first filled with $300 \mathrm{ml}$ DEPC-treated RNase-free water with $0.001 \%$ gelatin. The inlet of this sampler was put at a fixed height of 0.5 meter above the ground. The vacuum pump has a speed on $6 \mathrm{~L} / \mathrm{min}$ ( 6 liters air per minutes) to suck air. After 10 hours, a total of $3.6 \mathrm{~m}^{3}$ of air was sampled. The collected samples were stored at $-80^{\circ} \mathrm{C}$.

\subsection{Total RNA Extraction}

One hundred-milliliter samples were taken and subjected for ultrafiltration using Amicon Ultra-15 centrifugal filters. After the samples were concentrated to about $2 \mathrm{ml}$, the enriched samples ( $100 \mu \mathrm{l}$ each tube) were extracted by Trizol (Thermo). Following the manufacturer's protocol, total RNA of the sample was collected. Briefly, $100 \mu \mathrm{l}$ of the enriched sample was mixed with $1 \mathrm{ml}$ Trizol, and incubated at room temperature for 5 minutes to completely degrade cell membranes. After incubation, the lysed samples were added $200 \mu \mathrm{l}$ of chloroform, and mixed gently. Then, the sample was subjected for centrifugation $(12,000 \mathrm{~g}$ for 15 minutes at $4^{\circ} \mathrm{C}$ ). Upper aqueous layer was then pipetted into a new tube and $500 \mu$ isopropanol was added. The mixture was centrifuged for 12 minutes at $12,000 \mathrm{~g}$ at $4^{\circ} \mathrm{C}$. The supernatant was discarded and washed three times by $75 \%$ ethanol. Then, the pellet was air dried and dissolved into $20 \mu \mathrm{l}$ DEPC-treated RNase-free water.

\subsection{Total Genomic DNA Extraction}

When $100 \mu \mathrm{l}$ of the enriched sample was transferred into a $1.5 \mathrm{ml}$ tube containing $400 \mu \mathrm{l}$ of lysis buffer ( $1 \mathrm{mM}$ EDTA, $1 \%$ SDS, $10 \mathrm{mM} \mathrm{NaCl}, 20 \mathrm{mM}$ Tris-HCl, $\mathrm{pH}$ 8.2). Then, $100 \mu \mathrm{L}$ Proteinase $\mathrm{K}(20 \mathrm{mg} / \mathrm{mL})$ was added into the tube. After the whole mixture was vortexed to be homogeneous, it was incubated at $60^{\circ} \mathrm{C}$ for 6 hours. Equal volume of cold absolute ethanol was further added into the mixture and incubated for 1 hour on ice. The total mixture was subjected for high-speed centrifugation (14,000 rpm for 20 minutes), and the pellet was washed by $400 \mu \mathrm{l}$ of pre-cold $75 \%$ ethanol for three times. After the pellet was air dried, it was dissolved in $200 \mu \mathrm{l}$ autoclaved $\mathrm{ddH}_{2} \mathrm{O}$.

\subsection{RT-PCR}

cDNA was synthesized using random hexamer primers and mock reaction mixtures were run without reverse transcriptase. PCR was carried out using primers specific for a 212-bp segment of the influenza A virus matrix gene: forward pri- 
mer: 5'-CAGAGACTTGAAGATGTCTTTGCTG; reverse primer:

5'-GCTCTGTCCATGTTATTTGGATC. The One-Step RT-PCR kit from Qigene

(Cat No./ID: 210210$)$ was used, and the specific cycling conditions $\left(50^{\circ} \mathrm{C}\right.$ for 45 min, $95^{\circ} \mathrm{C}$ for $10 \mathrm{~min}$; and 50 cycles of $58^{\circ} \mathrm{C}$ for 30 seconds, $72^{\circ} \mathrm{C}$ for 30 seconds, and $95^{\circ} \mathrm{C}$ for 30 seconds) were applied.

\subsection{DNA Agarose Gel Electrophoresis}

After equal volume of samples was mixed with loading buffer, the mixture was loaded into wells of $0.6 \% \mathrm{TBE}$ agarose gel. Initially, $3 \mathrm{~V} / \mathrm{cm}$ was applied for 30 minutes; then $9 \mathrm{~V} / \mathrm{cm}$ was applied for about 1 hour. Then the bands stained with ethidium bromide. Images were taken using a UV transilluminator (Bio-Rad).

\subsection{RNA Non-Denaturing Agarose Gel Electrophoresis}

Taking $20 \mu \mathrm{lNA}$ aliquot and heating the sample at $70^{\circ} \mathrm{C}$ for 2 minutes, then immediately putting it on ice. After equal volume of RNA samples were mixed with loading buffer, the mixture was loaded into wells of $1.2 \%$ TAE agarose gel. Initially, $5 \mathrm{~V} / \mathrm{cm}$ was applied for 30 minutes, then $8 \mathrm{~V} / \mathrm{cm}$ was applied for about 1 hour. Then the bands were stained with ethidium bromide. Images were taken using a UV transilluminator (Bio-Rad).

\section{Results}

We carefully chose two rooms for this experiment, which mainly depends on their air-tight status and contains just one door and one air-tight window each room. Further, the two rooms have same size (width $\times$ length $\times$ height: 2.5 meter $\times 8.5$ meter $\times 2.4$ meter) with same volume, $51 \mathrm{~m}^{3}$. Before this experiment, we intentionally opened the windows to let environmental air enter into the room (Figure 1). We putted one FIR heating fan into one room, and powered it on at the 400 wattage for different time to generate dose gradients. After those treatments, we closed the door air-tightly and collected the air-particles in the room by a simplified air-particle collector (Figure $1(\mathrm{c})$ ).

After same amount volume of air was filtered, the collected particles in air were subjected for nucleic acid extraction. The result was shown in Figure 2. For double strand DNA, we could not detect its degradation significantly after FIR radiation (Figure 2(a)). However, for RNA, we readily found that RNA was sensitive to FIR radiation (Figure 2(b)). In a room with total volume $51 \mathrm{~m}^{3}$, after FIR radiation at 400 wattage for 30 minutes, RNA degradation was slightly shown. However, after FIR radiation at 400 wattage for 4 hours RNA degradation was significant.

Matrix protein 1 plays important roles in influenza B virus, including genome replication, virus entry, uncoating, assembly and budding, which is necessarily required for survival of the virus and serves as a unique marker for the virus [18] [19] [20]. In this study, we used Matrix protein 1 gene, briefly called matrix gene, as a biomarker to identify the influenza $\mathrm{B}$ virus, and confirmed that the 
(a)



Far infrared heating fan Or graphene FIR advice (b)

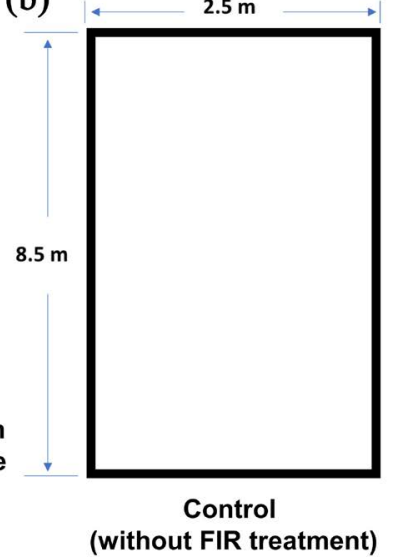

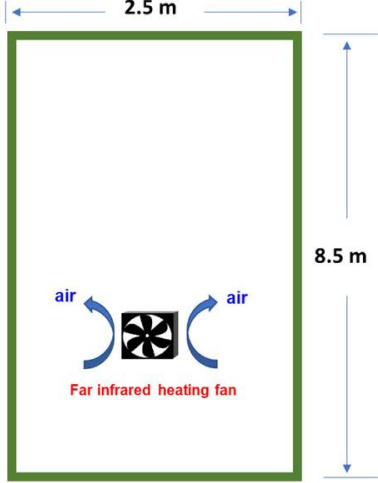

FIR treatment

(c)

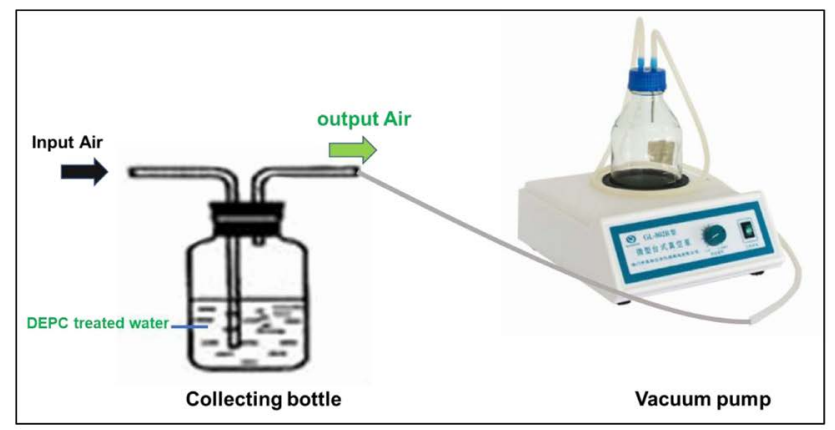

Simplified air particle Collector

Figure 1. Schematic representation of experimental design. (a) A diagram of FIR fan. It can swing its head and emit FIR radiation. (b) Tow rooms with same volume were used for those experiments. One is the control room without FIR radiation, the other was treated by FIR radiation with varied time. (c) A diagram for the manually prepared airborne microorganism collector. For preventing RNase contamination, DEPC treated bottle and water were used.
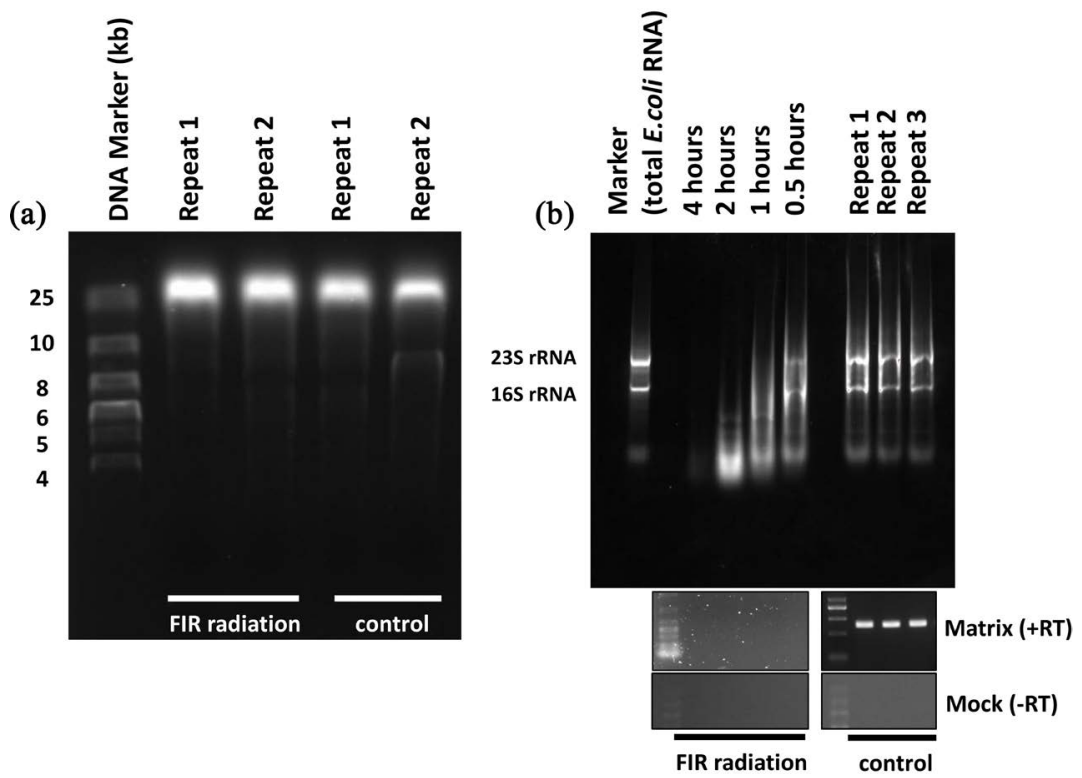

Figure 2. The FIR radiation induced degradation of RNA but not double strand genomic DNA in airborne microorganisms. (a) After FIR radiation, genomic DNA extracted from airborne microorganisms remained intact. (b) After FIR radiation, RNA from airborne microorganisms was degraded in terms of treatment time. The 212-bp segment of the influenza virus matrix gene was detected in the control samples without FIR radiation, but not in the FIR-treated samples. 
samples contained RNA viruses as the matrix gene of flu A virus in samples without FIR radiation was detected, but not in samples after FIR radiation for more than 30 minutes (Figure 2(b)). Further, under low dosage of FIR radiation the amount of total intact $23 \mathrm{~S}$ rRNA in airborne microorganisms was decreased as the dosage of FIR radiation increased (Table 1). We also tested FIR radiation originated from graphene, which can emit highly pure FIR, on inducing RNA degradation of airborne microorganisms, and obtained the similar result (Table 2 ), corroborating our previous observations shown in Figure 2. Then, this result indicates that FIR radiation under proper dosage is capable to induce degradation of single strand RNA, but not double strand DNA, in airborne microorganisms.

RNA viruses, such as influenza virus and COVID-19 virus, rely on their genetic materials, RNAs, for survival [21] [22] [23] [24]. As the data from in this study shows that FIR radiation is capable to induce RNA degradation in total airborne microorganisms, in theory FIR radiation has the potential to destroy RNA viruses in air. Based on this scientific deduction, we proposed two models for clinic treatments to RNA virus infection. First, in the RNA virus infected patient's home and infected open areas, FIR fan could be used to eliminate them in air. For non-infected homes and open areas, such as supermarkets and streets, FIR also could be applied to prevent RNA virus contamination and infection. The first model is shown in Figure 3(a). Secondly, RNA virus infected patients themselves could be treated by FIR radiation. FIR radiation could be applied directly into patient's mouth to diminish large amounts of RNA viruses on surface of cells, which could shut off the circulation of them and improve lung activation by absorbing fresh and clean air. As FIR radiation could improve cell proliferation [25], it might improve highly injured lung to recover. Further, as FIR radiation could penetrate about $4 \mathrm{~cm}$ tissue [26], it would be very helpful to apply FIR radiation to RNA virus infected patients' skin to improve cell activity and inhibit RNA virus in blood. The second model is shown in Figure 3(b).

Table 1. The efficiency of FIR fan treatment in low dosages on instability of total RNA in airborne microorganisms.

\begin{tabular}{cccccccc}
\hline & \multicolumn{7}{c}{$400 \mathrm{w}$ for $51 \mathrm{~m}^{3}$} \\
FIR Treatment (minutes) & control & 3 & 5 & 10 & 15 & 20 & 25 \\
\hline $\begin{array}{c}\text { The amount of } \\
\text { Intact 23S rRNA }\end{array}$ & 100 & 99 & 98 & 96 & 92 & 90 & 88
\end{tabular}

Table 2. The efficiency of graphene FIR treatment in low dosages on instability of total RNA in airborne microorganisms.

\begin{tabular}{cccccccc}
\hline & \multicolumn{7}{c}{$400 \mathrm{w}$ for $51 \mathrm{~m}^{3}$} \\
FIR Treatment (minutes) & control & 3 & 5 & 10 & 15 & 20 & 25 \\
\cline { 2 - 7 } & 100 & 98 & 95 & 93 & 88 & 87 & 85 \\
\hline $\begin{array}{c}\text { The amount of } \\
\text { Intact 23S rRNA }\end{array}$ & & & & & & & \\
\hline
\end{tabular}


(a)

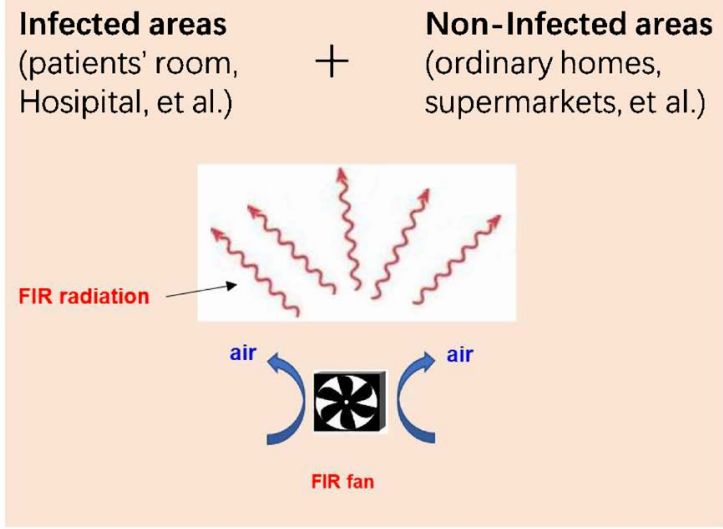

(b)

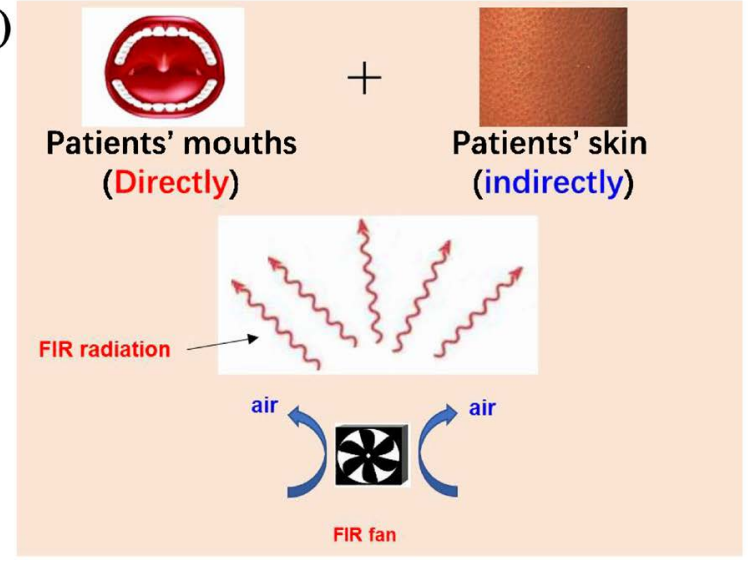

Figure 3. Two models for treatment of RNA virus, such as influenza virus and COVID-19 virus, by FIR radiation. (a) Elimination of environmental RNA virus by FIR radiation to prevent spreading and contamination of RNA virus. (b) Curing RNA virus infected patients by applying FIR radiation directly into the patients' mouths or on the patients' skin.

\section{Discussions}

As Beijing is a big city with considerable air contamination, we could not rule out the possibility that air pollution might play a role. Further, as the FIR heating fan is electronics for home usage and may contain small amount of near infrared, infrared and other light, which might contribute to the observed efficacy.

Currently, the exact molecular mechanism on how FIR radiation induces instability of RNA from airborne microorganisms is unknown. As RNA is subjected to spontaneous degradation under with high $\mathrm{pH}$, metal ions and high temperature [27] [28], it is possible that it might become fragile and break after the airborne microorganism is overheated after absorbing FIR energy.

The proposed two models on treatments for RNA virus infection, were sheer based on the fact that FIR radiation can induce degradation of RNA in airborne microorganisms; however, we could not completely rule out the possibility that some of them could survive by unknown mechanisms. Further, as the genomic DNA after FIR radiation was examined by agarose gel electrophoresis, it is possible that minor breaks in the genomic DNA were not detected largely by this method. Furthermore, FIR is considered to be quite safe, but excessive exposure 
to FIR is harmful to the skin and the eyes through photo-aging [29] [30]. Thus, usage of FIR radiation to prevent RNA virus contamination and cure RNA virus infection clinically should be carefully monitored by workers, nurses, doctors and therapists, which also need more clinical tests to confirm that FIR radiation truly mitigates the RNA virus infection in future.

Taken together, this study showed that single strand RNA from total airborne particles became unstable after FIR radiation. As RNA virus, such as influenza virus and COVID-19 virus, can survive in air [31] and is spreading worldwide, our study implies that FIR radiation might be a cheap, convenient, and efficient method that can be used immediately in clinic to treat the infection of those RNA viruses.

\section{Acknowledgements}

We are grateful to professor Fang-Zhen Sun (Institute of Genetics and Developmental Biology, Beijing) on supporting this study. We are also very grateful to professor Jun-Yuan Ji (Texas A\&M University) to give us suggestions on revising this paper. This work was supported by a grant from Ministry of Science and Technology (2012CB944903).

\section{Conflicts of Interest}

The authors declare no conflicts of interest regarding the publication of this paper.

\section{References}

[1] Okland, H. and Mamelund, S.E. (2019) Race and 1918 Influenza Pandemic in the United States: A Review of the Literature. International Journal of Environmental Research and Public Health, 16, 2487. https://doi.org/10.3390/ijerph16142487

[2] Taubenberger, J.K. and Morens, D.M. (2019) The 1918 Influenza Pandemic and Its Legacy. Cold Spring Harbor Perspectives in Medicine. https://doi.org/10.1101/cshperspect.a038695

[3] de St. Maurice, A. and Halasa, N. (2020) Preparing for the 2019-2020 Influenza Season. Pediatric Transplantation, 24, e13645. https://doi.org/10.1111/petr.13645

[4] Kandula, S., Pei, S. and Shaman, J. (2019) Improved Forecasts of Influenza-Associated Hospitalization Rates with Google Search Trends. Journal of the Royal Society, Interface, 16, Article ID: 20190080. https://doi.org/10.1098/rsif.2019.0080

[5] Thompson, W.W., et al. (2009) Estimating Influenza-Associated Deaths in the United States. American Journal of Public Health, 99, S225-S230. https://doi.org/10.2105/AJPH.2008.151944

[6] Wang, D., et al. (2020) Clinical Characteristics of 138 Hospitalized Patients with 2019 Novel Coronavirus-Infected Pneumonia in Wuhan, China. JAMA. https://doi.org/10.1001/jama.2020.1585

[7] Zhu, N., et al. (2020) A Novel Coronavirus from Patients with Pneumonia in China, 2019. New England Journal of Medicine, 382, 727-733.

[8] Shui, S., et al. (2015) Far-Infrared Therapy for Cardiovascular, Autoimmune, and Other Chronic Health Problems: A Systematic Review. Experimental Biology and 
Medicine (Maywood), 240, 1257-1265. https://doi.org/10.1177/1535370215573391

[9] Li, K., et al. (2017) Far Infrared Ray (FIR) Therapy: An Effective and Oncological Safe Treatment Modality for Breast Cancer Related Lymphedema. Journal of Photochemistry and Photobiology B: Biology, 172, 95-101. https://doi.org/10.1016/j.jphotobiol.2017.05.011

[10] Fujita, S., et al. (2011) Effect of Waon Therapy on Oxidative Stress in Chronic Heart Failure. Circulation Journal, 75, 348-356.

[11] Beever, R. (2010) The Effects of Repeated Thermal Therapy on Quality of Life in Patients with Type II Diabetes Mellitus. Journal of Alternative and Complementary Medicine, 16, 677-681. https://doi.org/10.1089/acm.2009.0358

[12] Oosterveld, F.G.J., et al. (2009) Infrared Sauna in Patients with Rheumatoid Arthritis and Ankylosing Spondylitis. A Pilot Study Showing Good Tolerance, Short-Term Improvement of Pain and Stiffness, and a Trend towards Long-Term Beneficial Effects. Clinical Rheumatology, 28, 29-34. https://doi.org/10.1007/s10067-008-0977-y

[13] Hausswirth, C., et al. (2011) Effects of Whole-Body Cryotherapy vs. Far-Infrared vs. Passive Modalities on Recovery from Exercise-Induced Muscle Damage in Highly-Trained Runners. PLOS ONE, 6, e27749. https://doi.org/10.1371/journal.pone.0027749

[14] Vatansever, F. and Hamblin, M.R. (2012) Far Infrared Radiation (FIR): Its Biological Effects and Medical Applications. Photonics \& Lasers in Medicine, 1, 255-266. https://doi.org/10.1515/plm-2012-0034

[15] Fischer, B.M. and Walther, M. and Jepsen, P.U. (2002) Far-Infrared Vibrational Modes of DNA Components Studied by Terahertz Time-Domain Spectroscopy. Physics in Medicine \& Biology, 47, 3807-3814. https://doi.org/10.1088/0031-9155/47/21/319

[16] Young, L., Prabhu, V.V. and Prohofsky, E.W. (1989) Calculation of Far-Infrared Absorption in Polymer DNA. Physical Review A, 39, 3173-3180.

https://doi.org/10.1103/PhysRevA.39.3173

[17] Wittlin, A., et al. (1986) Far-Infrared Spectroscopy on Oriented Films of Dry and Hydrated DNA. Physical Review A, 34, 493-500. https://doi.org/10.1103/PhysRevA.34.493

[18] Gotch, F., Rothbard, J., Howland, K., Townsend, A. and McMichael, A. (1987) Cytotoxic T Lymphocytes Recognize a Fragment of Influenza Virus Matrix Protein in Association with HLA-A2. Nature, 326, 881-882. https://doi.org/10.1038/326881a0

[19] Lyles, D.S., McKenzie, M. and Parce, J.W. (1992) Subunit Interactions of Vesicular Stomatitis Virus Envelope Glycoprotein Stabilized by Binding to Viral Matrix Protein. Journal of Virology, 66, 349-358. https://doi.org/10.1128/JVI.66.1.349-358.1992

[20] Zhirnov, O.P. and Klenk, H.D. (1997) Histones as a Target for Influenza Virus Matrix Protein M1. Virology, 235, 302-310. https://doi.org/10.1006/viro.1997.8700

[21] Shafiuddin, M. and Boon, A.C.M. (2019) RNA Sequence Features Are at the Core of Influenza a Virus Genome Packaging. Journal of Molecular Biology, 431, 4217-4228. https://doi.org/10.1016/j.jmb.2019.03.018

[22] Lu, C.W., Liu, X.F. and Jia, Z.F. (2020) 2019-nCoV Transmission through the Ocular Surface Must Not Be Ignored. The Lancet, 395, e39. https://doi.org/10.1016/S0140-6736(20)30313-5

[23] Zumla, A., et al. (2020) Reducing Mortality from 2019-nCoV: Host-Directed Therapies Should Be an Option. The Lancet, 395, E35-E36. 
https://doi.org/10.1016/S0140-6736(20)30305-6

[24] Li, X., et al. (2020) Transmission Dynamics and Evolutionary History of 2019-nCoV. Journal of Medical Virology, 92, 501-511.

https://doi.org/10.1002/jmv.25701

[25] Jeong, Y.M., et al. (2017) Preconditioning with Far-Infrared Irradiation Enhances Proliferation, Cell Survival, and Migration of Rat Bone Marrow-Derived Stem Cells Via CXCR4-ERK Pathways. Scientific Reports, 7, Article No. 13718. https://doi.org/10.1038/s41598-017-14219-w

[26] Mero, A., et al. (2015) Effects of Far-Infrared Sauna Bathing on Recovery from Strength and Endurance Training Sessions in Men. SpringerPlus, 4, Article No. 321. https://doi.org/10.1186/s40064-015-1093-5

[27] Holzer, A.M, Athar, M. and Elmets, C.A. (2010) The Other End of the Rainbow: Infrared and Skin. Journal of Investigative Dermatology, 130, 1496-1499. https://doi.org/10.1038/jid.2010.79

[28] Chiang, C. and Romero, L. (2009) Cutaneous Lymphoid Hyperplasia (Pseudolymphoma) in a Tattoo after Far Infrared Light. Dermatology Surgery, 35, 1434-1438. https://doi.org/10.1111/j.1524-4725.2009.01254.x

[29] Russell, A.D. and Harries, D. (1968) Damage to Escherichia coli on Exposure to Moist Heat. Applied Microbiology and Biotechnology, 16, 1394-1399. https://doi.org/10.1128/AEM.16.9.1394-1399.1968

[30] Kaga, E., Nakagomi, O. and Uesugi, S. (1992) Thermal Degradation of RNA-RNA Hybrids during Hybridization in Solution. Molecular and Cellular, 6, 261-264. https://doi.org/10.1016/0890-8508(92)90026-T

[31] https://www.cnbc.com/2020/03/16/who-considers-airborne-precautions-for-medica 1-staff-after-study-shows-coronavirus-can-survive-in-air.html 